describing the difficulties then being met with, owing to the remarkable density and solidity of the 'sudd' between Fashoda and Gondokoro, he states that he had just observed a herd of over two hundred elephants walking on the sudd over the river. When he returned to England for a short leave, before undertaking a similar survey up the Blue Nile, I asked him whether he had recorded a solid fact or was indulging in a traveller's tale, as it seemed a very extraordinary circumstance, if true. He was most emphatic, however, as to its being literally true, and that he had ceased to count the elephants after the two hundredth; also that he had been accompanied by a big-game hunter friend at the time, as well, of course, as by the Egyptian skipper and Sudanese crew of his little survey vessel, a specially fitted dahabeyah, all of whom were greatly interested in the unusual spectacle. It is referred to in the obituary notice of Mr. Loat's work which appeared in The Times of April 30, 1932."

\section{Memorial Tablet to Telford}

DURING the conversazione of the Institution of Civil Engineers held on June 2, the president, Sir Alexander Gibb, unveiled a small tablet in the newly completed extension of the main library recalling Telford's gift of books to the Institution. When Telford accepted the presidency in 1820, he wrote: "As proof of my sincere desire to promote the prosperity of the Institution, I beg leave to present it a collection of Books connected with the profession of a Civil Engineer ; they will form no inconsiderable portion of a suitable library, destined, I trust, at no distant period to become a valuable one. . . ." The library now contains 62,300 volumes, and Telford's books, with some others, have been placed in cases under the window in the west wall of the extension. Hollin's bust of Telford stands on the top of the cases, just above the tablet recalling his gift, while the oil paintings which the great engineer bequeathed to the Institution of the Pont Cysylltau Aqueduct and the Menai Bridge have been hung one on each side of the window.

\section{Hooker's Aneroid Barometer}

THE British Association has recently received from Miss Hooker, daughter of Sir Joseph Hooker, a gift of the aneroid barometer which used to hang by the fireplace in Charles Darwin's 'old study' at Down House, where it will now be replaced. A small repair has been kindly carried out by Messrs. Negretti and Zambra, and the aneroid is in working order. The face bears the words "Holosteric Barometer" and beneath them the figure 19, but no maker's name; the usual verbal indications of weather conditions are provided, and the dial is graduated continuously round the whole circle, figured from 25 in. up to 31 in., the remaining arc, between 31 and 25 in., being also graduated, as the whole scale is, in fiftieth parts of an inch. A small label, affixed perhaps when the instrument came into Hooker's possession, bears the name of "C. Darwin".

\section{New Central Botanical Gardens for Moscow}

Botanical gardens, to be known as the Central Botanical Gardens of the U.S.S.R., will shortly be constructed on the southern and northern slopes of the Lenin Hills, on the outskirts of Moscow, according to the Soviet Union Year Book Press Service. The gardens will occupy a site of 825 acres, bounded by the projected Rublevskoye Chaussee, the Palace of Soviets, the Andreyev Canal and the Moscow River. A considerable part of the site will be used as a scientific research station. Special hothouses and structures will be put up in this section for the purpose. The middle of the Gardens will have a group of hothouses with varying artificial climates for the growing of plants from all over the world. A model orchard will be used for showing Michurin and other horticultural experiments. The Botanical Gardens will be attractively laid out with terraces, fountains and waterfalls. A funicular railway will connect the Moscow River Embankment with the top of the Lenin Hills. The Academy of Sciences of the U.S.S.R. has appointed a special commission to take charge of the designing and construction of the Gardens. The Commission includes V. L. Komarov, president of the Academy, Prof. N. I. Vavilov, Prof. B. A. Keller, A. M. Lezhav, director of the Central Department of Sub-Tropical Crops of the Com. missariat of Agriculture of the U.S.S.R., and I. S. Gorshkov, director of the Michurin Central Laboratory of Genetics.

\section{Future of the Coal Gas Industry}

THE seventy-fourth annual meeting of the Institution of Gas Engineers was held on June 1-4, under the presidency of Mr. Stephen Lacey, of London. The papers contributed illustrated the problems and trends of the gas industry to-day-the tendency gathering in momentum on one hand to replace the consumption of raw coal by smokeless fuels and methods, and on the other to use fuels in a 'fluid' form amenable to ready and automatic control. The gas industry as a producer of smokeless fuels-both solid and fluid-is deeply involved in this trend, and the papers read retailed divergent opinions as to the future. A major problem of the industry is to maintain an economic balance between coke and gas. In Great Britain, gas engineers do not anticipate an early displacement of solid fuels; the industry must look for a combination of the two. Mr. C. F. Broadhead, of Melbourne, Australia, influenced by the acute instability of markets for by-products in that country, favoured concentration on complete gasification of coal. This idea, which is by no means new, is attracting renewed attention, and as $\mathrm{Mr}$. Lacey said, is now the aim of an important branch of the Institution's research work. The uncertainty about the future of the supplies of suitable gas coal has stimulated interest in this problem. It has long been felt that the service of the gas industry would be more efficiently rendered if organized into larger units. Such an organization of the electrical industry has been imposed by law and a somewhat analogous process is now proceeding in the gas industry, but 
voluntarily, and by the formation of corporations or holding companies. This process has evoked a mixed reception, and a parer by Mr. G. M. Gill records how the holding companies have already given technical and financial assistance to many small isolated companies, enabling them to pursue a more progressive policy.

\section{A Meteorological Chronology}

Geophysical Memoir No. 70 of the Meteorological Office, by C. E. Britton, is entitled "A Meteorological Chronology to A.D. 1450". It is a symposium of various compilations of historical references to the weather of the British Isles, and a full bibliography of these is given at the end of the memoir. The main body of the work is in diary form, each year for which any notable meteorological event has been recorded appearing in turn, with particulars of such events. The first year is 2668 B.c., but it is pointed out that these very early dates, derived from such sources as the Irish Chronicles, are "largely legendary", being probably in the nature of oral traditions. The events chronicled in these years are chiefly the overflowing of various Irish lakes and rivers. The traditional period is followed by the Roman period, and the author points out that the very large number of meteorological events assigned to those times by various annalists and chroniclers do not appear to have been recorded by any contemporary writer; many indeed aprear for the first time on record in the eighteenth century, with no information from the chronicler as to where the information was obtained. A typical specimen of this class of record is that of Dr. Thomas Short of Sheffield, who published a "General Chronological History of the Air, Weather, Seasons, Meteors, Etc." in two volumes in 1749-a work that occupied the worthy doctor for fifteen years. Without disputing the interest attaching to a work of the character of this symposium, one may doubt if its scientific value for meteorology is appreciable. It is amusing to notice the sobering of the record in its later years-the gradual dying out of such events as several days' downpour of blood, for example--with its suggestion that a very large part of the events before, say, A.D. 1000, are pure inventions or unrecognizable distortions of happenings not so very different from those of modern times.

\section{A Theory of Atomic Structure}

OUR attention has been directed to a theory of atomic structure which has been elaborated by Mr. C. F. Krafft, of Washington, D.C., and published by him in book form under the title "The Mechanistic Autonomy of Nature, with 1935 and 1936 Supplements". In this theory the atomic nucleus has been discarded in favour of a system of vortex rings arranged in the form of polygons, which may break up into chemically active groups and then fuse with other similar groups to form larger polygons. Thus the valency 'bonds' are made up of protons as well as electrons and the structural centre of the atom is apparently void. Whether this theory will survive the critical examination of the physicist is not certain, but the author claims that it enables him to interpret the chemical structures of compounds like diborane $\mathrm{B}_{2} \mathrm{H}_{6}$, etc., which are apparently anomalous. $\mathrm{He}$ asserts that "the very existence of diborane flatly disproves the entire nuclear theory of atomic structure, and not even its endorsement by high authorities can save it". In view of this bold statement, it is interesting to recall the fact that this very problem was brilliantly solved quite recently by Dr. E. Wiberg, an account of whose work on the subject was published in Nature of February 27, p. 381.

\section{Storage Battery Cars}

RECENT progress in the design of storage batteries has turned the attention of traction engineers to developing storage battery cars for use on rails. These cars are very trustworthy in service and simple to operate. The maintenance costs of the equipment are much lower than when Diesel engines are used. Battery maintenance is usually carried out by the manufacturers on the basis of the number of miles run, and the cost depends on the current price of lead. The 'standstill' charges affect about ten per cent of the total stock in service, and due to battery overhauls they are usually out of commission for three or four days during the year. According to Electrical Industries of May 19, charging the batteries is very simple. It is carried out at night by connecting them to a power supply, and when fully charged the current is automatically switched off. At the terminal points of the system the whole battery can be replaced in a quarter of an hour. The distance that can be covered in a single battery charge is now 185 miles. Trials on the German State Railways show that some cars can travel for 250 miles non-stop at 25 m.p.h., and half that distance can ke covered at 40 m.p.h. In the first case the power consumption is 18 watt hours per ton mile and in the second 26 watt hours per ton mile. At the present time, there are 170 cars on the German State Railways and their average speed is between 37 and 47 m.p.h. The average yearly car mileage during 1935 was 38,500 . In Poland, France and the north of Italy, storage battery cars, mostly of the double bogie type, are run on tramways and suburban lines. Each car carries about a hundred passengers and has four motors giving a total of about 180 horse-power.

\section{The National Physical Laboratory.}

THE annual report of the Laboratory for 1936 is presented in a new form. Hitherto it has been a quarto volume of about 250 pages, well illustrated and cost $12 s$; now it is royal octavo of 144 pages without illustrations but costs only $2 s .6 d$. The saving of space has been secured by the omission of detail of limited interest. The death of Sir Joseph Petavel, the director, was referred to in the last report and until the appointment of a successor Sir Frank Smith was in charge. Several members of the staff have been transferred to other Government Departments or have been absorbed by industry. Many of the senior members have taken part in conferences at home and abroad and have lectured in provincial centres of industry on the work of the 